\title{
O caminho das imagens: três histórias de filmagens na primavera-verão de 1944
}

\section{The images' path: three stories of film-making in the spring-summer of 1944 \\ Sylvie Lindeperg}

A partir dos anos 1990, as indústrias culturais passaram a manifestar cada vez mais "gosto" pelas imagens de arquivo. Colorizadas, sonorizadas, submetidas à trepidação da montagem, valorizadas pelo argumento comercial do inédito, essas imagens adulteradas, empobrecidas, transformadas em lugares-comuns e em ícones comerciais perderam grande parte de sua historicidade. Também no mesmo período, foram realizados trabalhos de pesquisa sobre a migração, a reutilização, a poética das imagens de arquivo, segundo uma dupla perspectiva estética e histórica. Nesse campo de pesquisa em pleno florescimen-

Sylvie Lindeperg é doutora em História e professora na Universidade Paris I - Panthéon Sorbonne, França (sylvie.lindeperg@gmail.com).

Este texto sintetiza as reflexões desenvolvidas pela autora em $L$ a voie des images. Quatre histoires de tournage au printemps-été 1944 (Lagrasse: Verdier, 2013).

Artigo recebido em 24 de janeiro e aprovado para publicação em 20 de março de 2013.

Tradução de Jean Loup Jospin revista por Dora Rocha. 
to, um território permanece, contudo, bastante inexplorado: ele está ligado ao momento singular do registro da imagem.

É essa volta ao ponto de origem das imagens, essa historicização do registro que eu gostaria de recuperar aqui. Tratarei, com esse objetivo, de três filmagens iniciadas na primavera-verão de 1944: em Paris, no momento da Liberação, e nos campos de Terezín, na Tchecoslováquia, e de Westerbork, na Holanda. Esses planos filmados em situações extremas permitem entrever o universo mental daqueles que os filmaram. Eles revelam seu imaginário a respeito do evento, sua vontade de conformá-lo à ideia que fazem dele, às vezes sua dificuldade de perceber seu encadeamento. Essas imagens recolhem também o impensado de uma época. Elas conservam o que escapou ao olhar do cameraman na gravação mecânica de uma fatia do real. Essas "fugas de sentido"1 se exprimem através de elementos discretos que se encontram nos planos. Seguir o caminho das imagens consiste em restituir-lhes a iniciativa, prestando atenção aos sinais instáveis de que elas são depositárias.

Essa abordagem exige a adoção de uma "visão próxima" do cinema, atenta aos detalhes e aos indícios, aos panos de fundo e aos personagens secundários. Ela se inspira no modelo estabelecido por Daniel Arasse para a pintura quando ele preconiza "uma prática próxima do pincel e do olhar" e define o detalhe como o "lugar de uma experiência" (Arasse, 1992, reed. 1996). Ela supõe que se entre em intimidade com o "corpo dos filmes". Ela passa pela descrição detalhada, a câmera lenta, os retornos pacientes diante da imagem. Os planos analisados abrem assim o caminho, até mesmo em sua fragilidade e em suas lacunas, para uma história do sensível próxima daqueles que fizeram o evento, foram seus vencedores ou suas vítimas.

\section{A Liberação de Paris: o ausente da história}

O filme La Libération de Paris foi rodado em agosto de 1944, a partir do início do levante, por iniciativa do Comitê de Liberação do Cinema Francês (CLCF), grupo de resistência de orientação comunista. As imagens, combinadas a um comentário de Pierre Bost, foram projetadas para os parisienses a partir do dia 29 de agosto de 1944. Nas semanas seguintes, o documentário alcançou um imenso sucesso na França e no exterior.

La Libération de Paris aparece, de fato, como o filme da comunhão. A equipe realizadora celebrou com ecumenismo a entidade abstrata de uma capital em luta por sua liberação: à lógica partidária que teria consistido em homenagear apenas os membros da Resistência, e em particular os comunistas, o CLCF preferiu uma estratégia de conquista e sedução de um grande público ao qual es- 
tendeu o espelho lisonjeiro de um povo resistente. Além disso, se La Libération de Paris reduzia os soldados da França livre ao papel de supletivos, ele dava toda a importância ao general de Gaulle e ao momento de graça dos reencontros parisienses. La Libération de Paris serve de fato à gesta oficial em duas longas sequências consagradas ao discurso do Hotel de Ville e ao desfile nos Champs-Elysées. As imagens do dia 26 de agosto montadas pelo CLCF contribuíram amplamente para coproduzir o evento: em perfeita simbiose com a operação político-simbólica acionada pelo general de Gaulle, elas deram ao desfile sua plena dimensão de consagração republicana.

Os planos escolhidos foram filmados pelos câmeras Gaston Madru (instalado em cima de um carro travelling), Georges Méjat, encarregado de fazer "croquis" da multidão, e o jovem Gilbert Larriaga, que cobriu o desfile a pé, desde o Arco do Triunfo até os Cavalos de Marly. Os cameramen acompanham a descida majestosa do general de Gaulle, dominando com sua altura os integrantes do cortejo, e colocando-se um passo adiante deles para receber a homenagem e as aclamações de uma enorme multidão que gritava seu nome, parisienses amontoados ao longo do percurso, empoleirados em promontórios, pencas humanas acompanhando a forma dos postes de iluminação. "Ah! É o mar", escreveria mais tarde o memorialista. O comentário de Pierre Bost acompanha o diapasão gaullista quando evoca aquele "dia do triunfo e da certeza": "O general De Gaulle, chefe do governo provisório da República Francesa, vai atravessar a capital sobre um tapete voador de aclamações [...] Ele desce os Champs-Elysées a pé, sem fausto, misturado à tropa daqueles que lutaram com ele fora da França e dentro da França". A escolha da montagem em campo e contracampo, os planos do General se seguindo aos da população entusiasmada, tornam mais sensível a troca de olhares constitutivos dessa "taumaturgia visual" (Lardellier, 1997: 40) desejada por Charles de Gaulle. A exposição de seu corpo permite ao chefe do governo provisório realizar o milagre da regeneração da comunidade nacional; a restauração da legalidade republicana passa pela exibição física do General poderoso, concebido como a encarnação do Estado renascente.

Os planos não utilizados pelos montadores do $\mathrm{CLCF}^{2}$ lançam luz sobre sua dupla estratégia de polimento e re-enquadramento do evento. Eles dão plenamente a ideia de um desfile preparado às pressas, em grande parte sob controle, mas mesmo assim correndo grandes riscos, já que ainda se travavam combates no subúrbio norte de Paris e o inimigo ainda rondava pelas ruas. Descobrimos assim no copião cenas de desordem e de pânico que prejudicaram a bela ordenação da cerimônia gaullista, quando atiradores de elite emboscados nos telhados atiraram na multidão na Place de la Concorde e na Notre Dame. Os planos não montados revelam também a improvisação do desfile e a presença maciça de repórteres que vieram imortalizá-lo. Em La Libération de Paris, somente o gesto fa- 
moso de Georges Bidault ${ }^{3}$ agitando os braços para afastar um nevoeiro invisível nos permite imaginar a incrível multidão diante da primeira linha do cortejo.

Figura 1

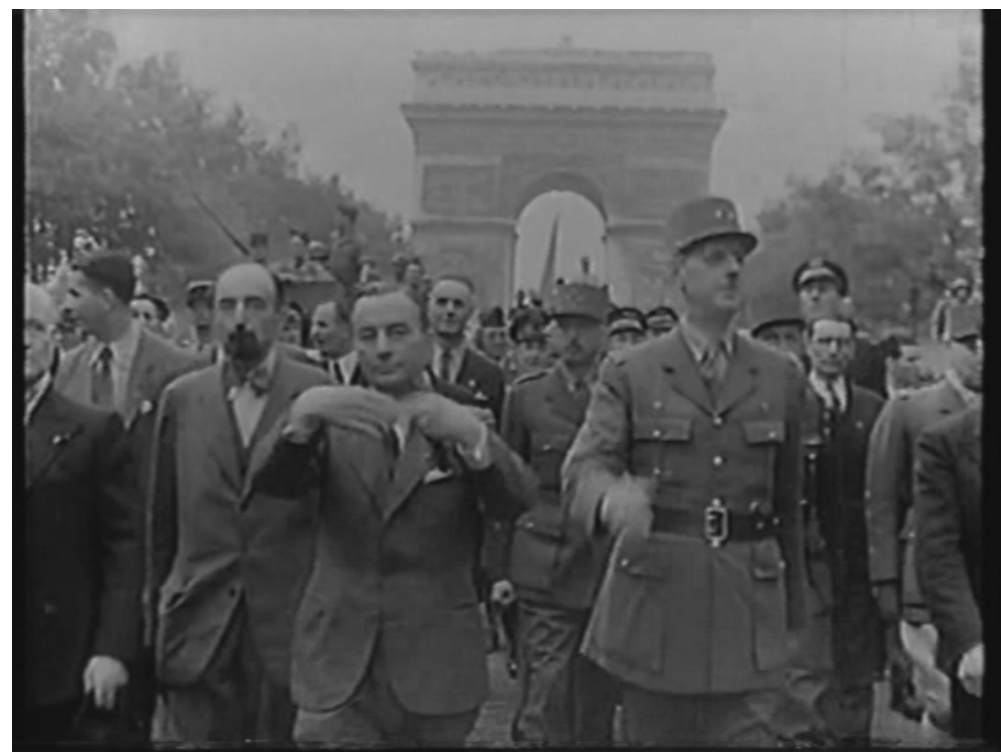

A horda aparece nos planos não montados que revelam o atropelo dos fotógrafos e dos cinegrafistas, enquadrando e invadindo o cortejo a pé ou amontoados nos carros da imprensa. Os cinegrafistas do CLCF haviam compreendido o reflexo desdobrado do evento e de sua "midiatização". Ao fechar o campo, o filme impunha a imagem de uma comunhão sem intermediários entre de Gaulle e os franceses, promovendo a imagem de uma troca direta de homenagens entre a multidão e o chefe do governo provisório.

Colocar lado a lado as imagens de La Libération de Paris e os planos não utilizados permite assim multiplicar os pontos de vista sobre o evento e alargar o quadro em que o filme oficial foi rodado. As imagens esquecidas revelam ainda a presença de personagens secundários e de microeventos desprezados pelos montadores do CLCF. No copião do filme, um plano filmado na Place de l'Etoile permite entrever um combatente negro, com o braço na tipoia, que segue de perto o herói do dia. Esse personagem aparece três vezes em La Libération de Paris, onde ele permanece sem nome e sem destino: podemos vê-lo escoltar um soldado alemão; socado em cima de um tanque conquistado; amparado por dois companheiros, com o braço sangrando após um tiroteio. 
Figuras 2 e 3
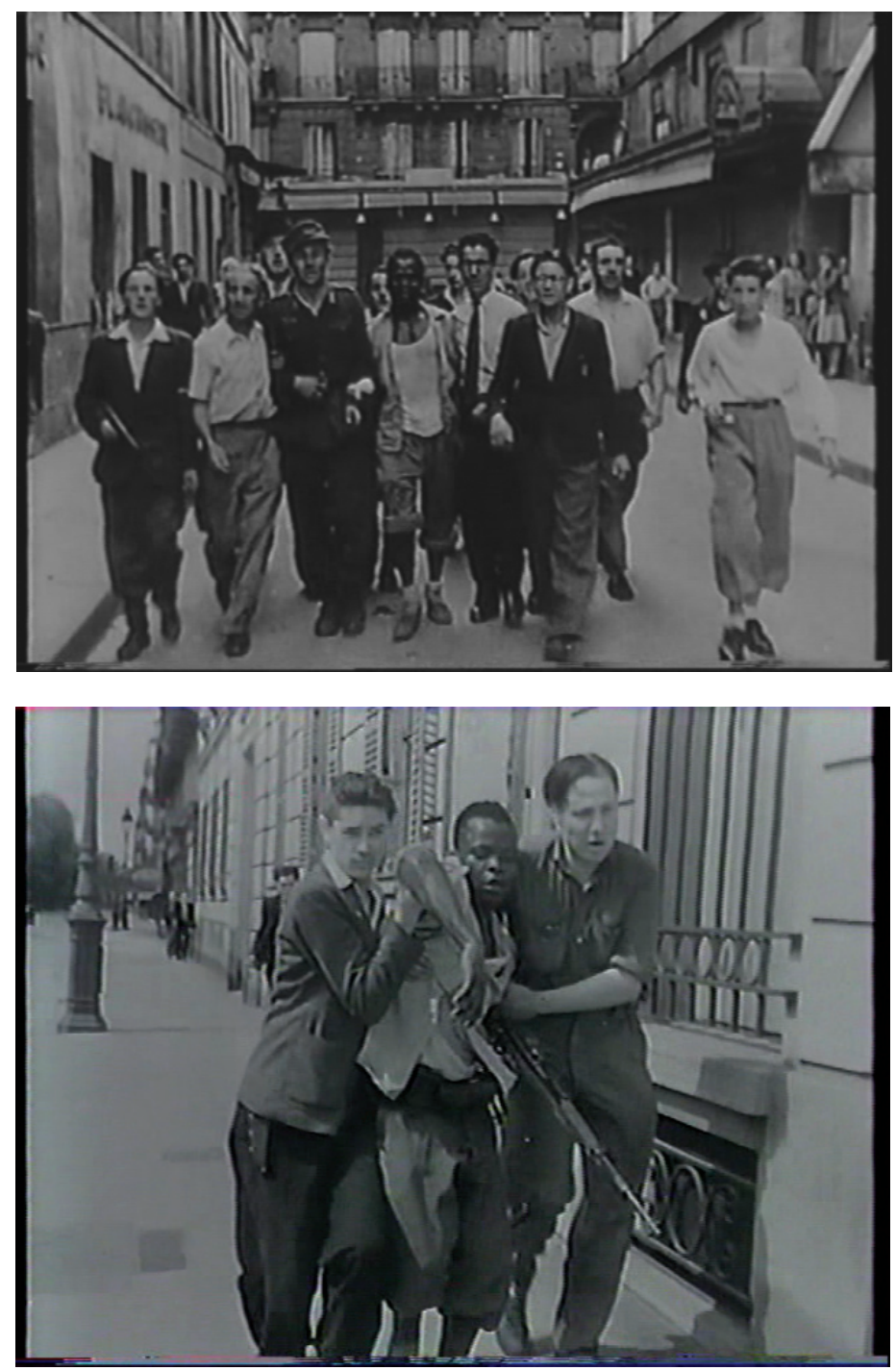

Chamado Georges Dukson e originário do Gabão, esse antigo prisioneiro de guerra evadido vivia de pequenos furtos em um hotel em Batignolles quando soou a hora da Liberação (Dunan, 1945: 243-267). No dia 19 de agosto de 1944, quando as Forças Francesas do Interior recuperaram a Prefeitura do XVII 
arrondissement, ele se voluntariou e participou de todos os combates da rue de Rome e do boulevard des Batignolles, escoltando as patrulhas, atacando os caminhões inimigos, disparando contra os atiradores alemães e conquistando um tanque da Wehrmacht. Ferido no braço durante um choque, Dukson não podia mais segurar um fuzil, mas voltou ao ataque, armado de garrafas incendiárias. Apelidado de "Leão Negro do XVIIème", esse combatente esplêndido, com seus rugidos, não passou despercebido em Batignolles. ${ }^{4}$ Mas no dia 26 de agosto, promovido a subtenente das FFI, Dukson, em plena glória, começou a perder o senso de medida: achou que poderia se infiltrar no cortejo do general de Gaulle. De fato, as tomadas do CLCF o mostram no pé do Arco do Triunfo, misturado aos homens de Leclerc, a alguns passos do general de Gaulle, tal como o Zelig de Woody Allen. Dois planos filmados por cineastas amadores completam a cena. No primeiro, filmado alguns segundos mais tarde, o "Leão Negro" reaparece: ele manteve sua posição e se encontra a menos de um metro do General, que o encobre em grande parte, permitindo perceber somente o ponto branco do seu braço na tipoia. A continuação do plano em câmera lenta revela o gesto firme de um aluno da Escola Militar de Saint-Cyr tocando-o no ombro de forma a fazê-lo recuar, abrindo caminho para o prefeito Flouret. O homem camaleão reaparece, no entanto, nos primeiros minutos da descida dos Champs-Elysées: em um segundo plano filmado pelos amadores, o vemos caminhar orgulhosamente do lado esquerdo do General de Gaulle, a camisa abotoada, as meias muito bem esticadas. $\mathrm{E}$ a vez de um oficial barrar-lhe o caminho, intimando-o com um gesto a deixar o cortejo. Duas fotografias permitem prolongar a cena: na primeira, Dukson se protege com o braço bom da agressão invisível; na segunda, um soldado aponta a metralhadora na direção do intruso. ${ }^{5}$ Retirado manu militari do cortejo, Dukson não aparece mais nas imagens do desfile. Na cerimônia de renascimento do Estado Republicano, o ardoroso combatente do XVIIème já era um indesejável, e logo seria um vencido da história.

De volta à vida civil, transformado em uma celebridade local, Dukson não quis retomar o curso de uma existência miserável. ${ }^{6}$ Requisitando uma antiga garagem alemã, ele se lançou ao mercado negro, a roubos e perquirições abusivas, como um herói equivocado de Cayatte. Por ordem das autoridades militares, as FFI procederam à sua captura para conduzi-lo à prisão do Monte Valérien. Aproveitando-se de uma parada, Dukson fugiu e foi atingido por uma bala que despedaçou sua coxa. Morreu enquanto era operado no Hospital Marmottan.

Portanto, os cameramen e os fotógrafos que cobriram o desfile registraram uma das últimas imagens de Dukson. Esses planos e essas fotografias têm a ver com o que Lessing (1990, reed. 2002) chama de um "instante pregnante". Eles permitem ao espectador imaginar e conceber, ao invés de ver os momentos extremos, "o que já se passou e o que vai acontecer": a glória efêmera de Dukson 
seguida da morte em desgraça, anunciada pela arma apontada do clichê. Uma das propriedades da imagem fotográfica e cinematográfica reside nessa dimensão conservadora. $\mathrm{O}$ registro mecânico permite salvaguardar, frequentemente por intromissão, o vestígio dessas "pessoas comuns" mais tarde esquecidas, que Michel de Certeau (1973) designa como os ausentes da história.

Figura 4

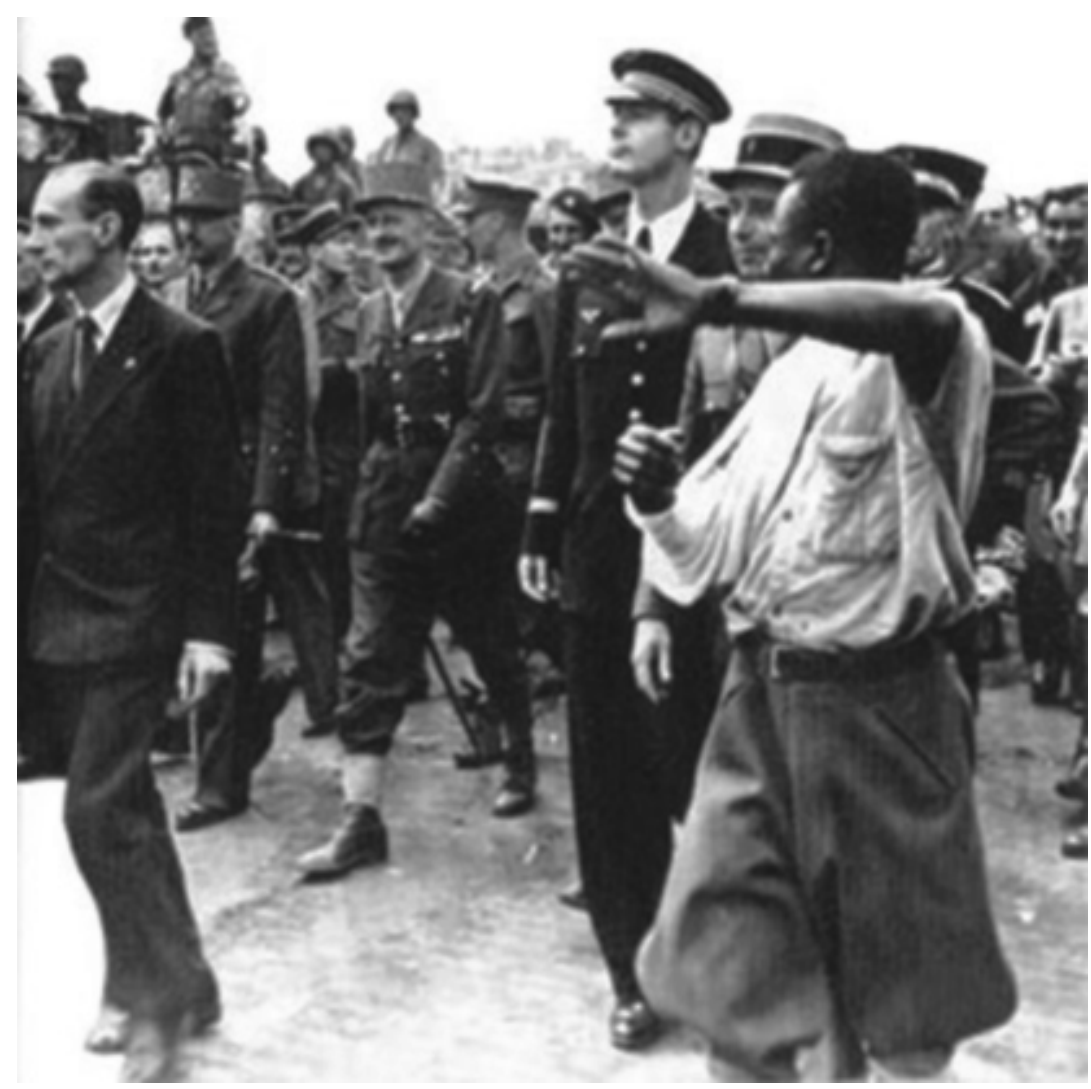

Dos esquecidos às vítimas, o cinema também tem a capacidade de voltar as imagens de propaganda contra aqueles que as registraram, transformando em fantasmas esses seres frágeis e ameaçados, capturados na armadilha da encenação. Sua presença espectral se exprime de maneira exemplar nos fragmentos do filme que foi rodado em 1944 no campo-gueto de Terezín, em perfeita sincronia com La Libération de Paris. 


\section{Terezin: o canto dos fantasmas}

Na obra Austerlitz (2002, reed. 2008), Sebald descreve a pesquisa do herói epônimo em busca de vestígios de sua mãe, desaparecida em Terezín. Seu personagem examina pela primeira vez um filme rodado no verão de 1944 no campo-gueto: ofuscado pela reverberação das imagens, Austerlitz se vê às voltas com o brado alto e contínuo da propaganda. Tem então a ideia de mandar fazer uma cópia gravada em câmera lenta. Rompendo o véu da propaganda, as imagens de Theresienstadt se transformam em uma lenta dança de espectros: e súbito, na borda superior de um plano, lhe aparece o rosto de uma mulher que mal se destaca da sombra escura, que poderia ser sua mãe, a atriz Agata. O uso da câmera lenta traz de volta à luz um rosto de além-túmulo ao mesmo tempo em que descontamina as imagens de propaganda.

Transmitido à posteridade com o título apócrifo Der Führer schenkt den Fuden eine Stadt (O Führer oferece uma cidade aos Fudeus), o filme gravado em agosto e setembro de 1944 chamava-se originalmente Theresienstadt. Ein Dokumentarfilm aus dem jüdischen Siedlungsgebiet (Terezín. Documentário sobre a zona de povoamento judeu.${ }^{7}$ Ele foi realizado no prolongamento da visita que a delegação da Cruz Vermelha Internacional, conduzida por Maurice Rossel, havia feito no dia 23 de junho de 1944 ao campo-gueto transformado na aldeia Potemkin. A iniciativa do filme se deveu a Hans Günther, responsável pelo Escritório de Assuntos Judaicos da Gestapo de Praga, que o financiou com o dinheiro confiscado aos judeus tchecos (Margry, 1992: 149). Lançado em dezembro de 1943, o projeto tinha por objetivo apresentar Terezín como um lugar de vilegiatura paradisíaco e dissimular sua função de campo de trânsito para os centros de execução. O cineasta Kurt Gerron, ${ }^{8}$ cercado de uma equipe de internados judeus, trabalhou sob a supervisão de Karl Rahm, o comandante do campo, e de Karel Peceny, o diretor da produtora do jornal cinematográfico de Praga Aktualita. A produtora tcheca forneceu também os dois cameramen, Ivan Fric e Cenek Zahradnicek. No meio do caminho, Peceny passou a controlar o cineasta, que foi relegado ao papel de simples assistente. Tão logo a filmagem terminou, Kurt Gerron foi deportado com grande parte de sua equipe e várias pessoas filmadas; o cineasta foi assassinado logo que chegou a Auschwitz. Em março de 1945, Fric garantiu a montagem das imagens e do som.

Concebido prioritariamente para a Cruz Vermelha Internacional e países neutros, Theresienstadt não tinha o propósito de ser distribuído na Alemanha. Segundo o historiador Karel Margry, quatro projeções foram organizadas entre o final de março e o início de abril (três delas no próprio campo de Terezín) ${ }^{9}$ antes que as bobinas desaparecessem sob os escombros do III Reich. Fragmentos do filme reapareceram durante os anos 1960 permitindo recompor cerca de $20 \mathrm{mi}$ nutos. ${ }^{10}$ 
Theresienstadt tira seu cenário e suas situações da visita da Cruz Vermelha. Gerron explora as adaptações feitas para enganar os visitantes: o pavilhão das crianças com seu carrossel e seus balanços; a quadra de esportes montada no terreno contíguo às muralhas; a sala de leitura; as lojas falsas com suas vitrines bem abastecidas; os espaços verdes da praça do mercado e seu coreto... O roteirista inspirou-se também em alguns eventos da visita, tais como o do lanche, encenado uma primeira vez no dia 23 de junho de 1944 na presença do comandante do campo. Nesse dia, latas de sardinha foram distribuídas às crianças, que receberam ordem de agradecer ao "tio Rahm"; assim que os delegados partiram, as latas foram confiscadas. A equipe de filmagem ofereceu por sua vez fatias de pão com margarina que foram devoradas antes da gravação pelos jovens atores esfomeados, obrigando a equipe a recomeçar três vezes a cena.

\section{Figura 5}

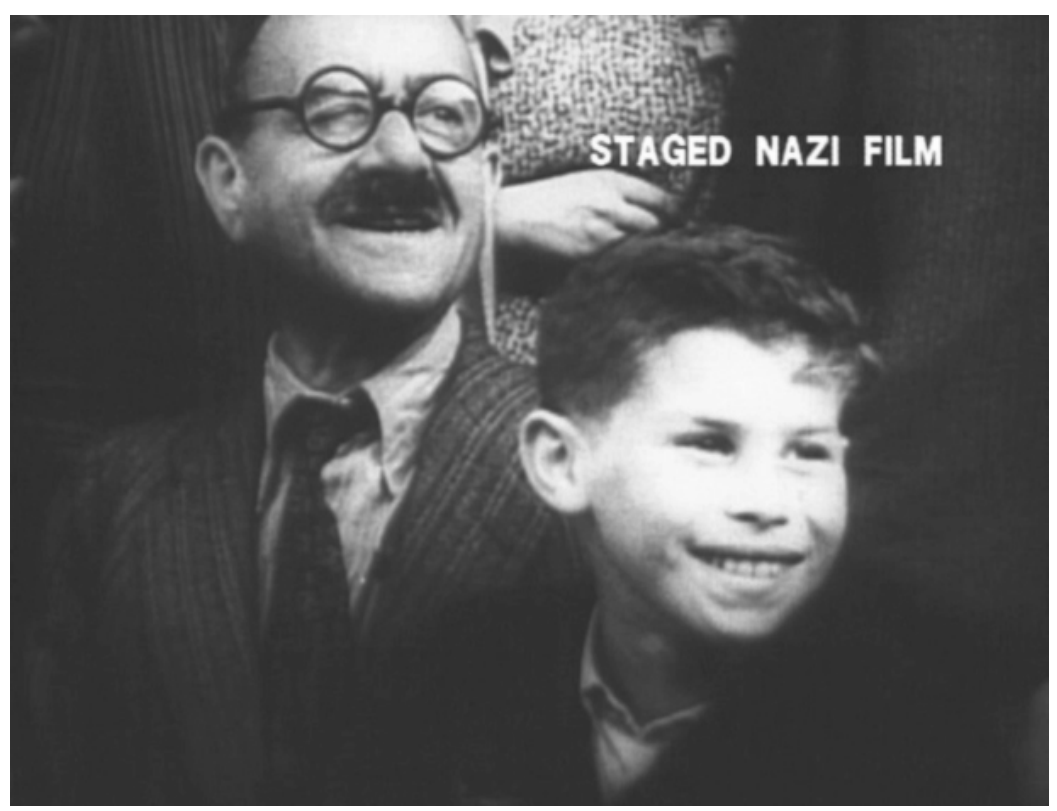

Mais ainda que a visita da Cruz Vermelha, o filme Theresienstadt consegue se emancipar do real ao excluir do campo as torres de vigilância, o comandante e os guardas. Ao deslizamento semântico do título - o campo-gueto tornou-se "zona de povoamento" - corresponde a escamotagem das condições da internação que transforma os detentos judeus em cidadãos livres de uma "cidade normal da província". ${ }^{11}$ A história alimenta igualmente a ficção de uma vida fa- 
miliar, cuja ausência fora lamentada por Rossel em seu relatório elogioso. A penúltima sequência de Theresienstadt, mostrando três crianças, seus pais e avós reunidos ao redor de uma mesa para o jantar, é duplamente falsa. Além de as crianças, mulheres e homens viverem separados no campo-gueto, as famílias haviam sido tragicamente desmembradas pelas deportações. A equipe produtora precisou apelar para os Cohen de Amsterdã e os Kozower de Berlim para compor a cena. Algumas semanas mais tarde, a família Kozower foi enviada para a morte. Essa escolha de personalidades eminentes nas comunidades judaicas de Berlim e Amsterdã não deixa de causar espanto: negligência, inconsequência ou lapso, ela afirmava para a posteridade a farsa da filmagem.

Em Theresienstadt, a camuflagem passa também pela encenação de uma comédia da felicidade, expressa no jogo forçado dos risos e sorrisos.

Por excesso de zelo, o totalitarismo da alegria é levado ao absurdo nas cenas de hospital que mostram doentes surpreendentemente sorridentes, expressando seu bem-estar diante da câmera. ${ }^{12} \mathrm{~A}$ dissimulação passa também pela fuga dos olhares, que assinala os artifícios da encenação e as ordens dadas às pessoas filmadas. No conjunto dos planos conservados, os olhares para a câmera são raros: mesmo os figurantes filmados de frente, em close-up, se empenham em ignorar o equipamento.

Figura 6

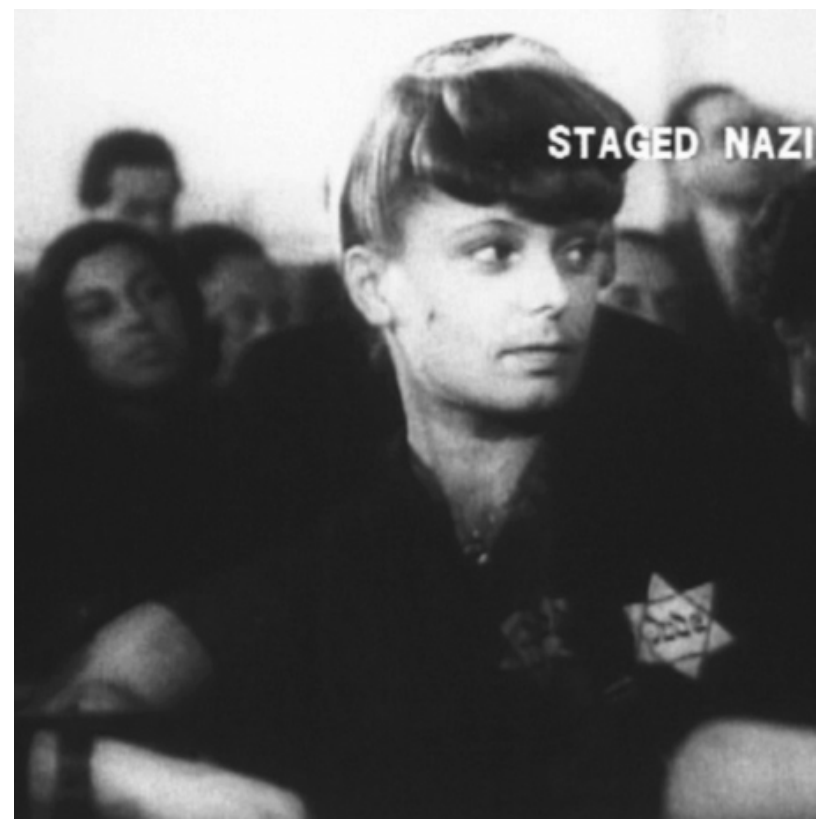


O evitar do face a face com a câmera revela outra dimensão ficcional de Theresienstadt. Como destaca Jean-Louis Comolli (2009: 29), o fato de se comportar diante da câmera "como se não estivesse sendo filmado" sinaliza a representação do comediante (profissional ou não) e constitui uma das características da ficção cinematográfica: "como se a câmera se tivesse tornado transparente, invisível", a ficção no cinema consiste em primeiro lugar em mentir "sobre suas condições de produção".

Figuras 7 e 8
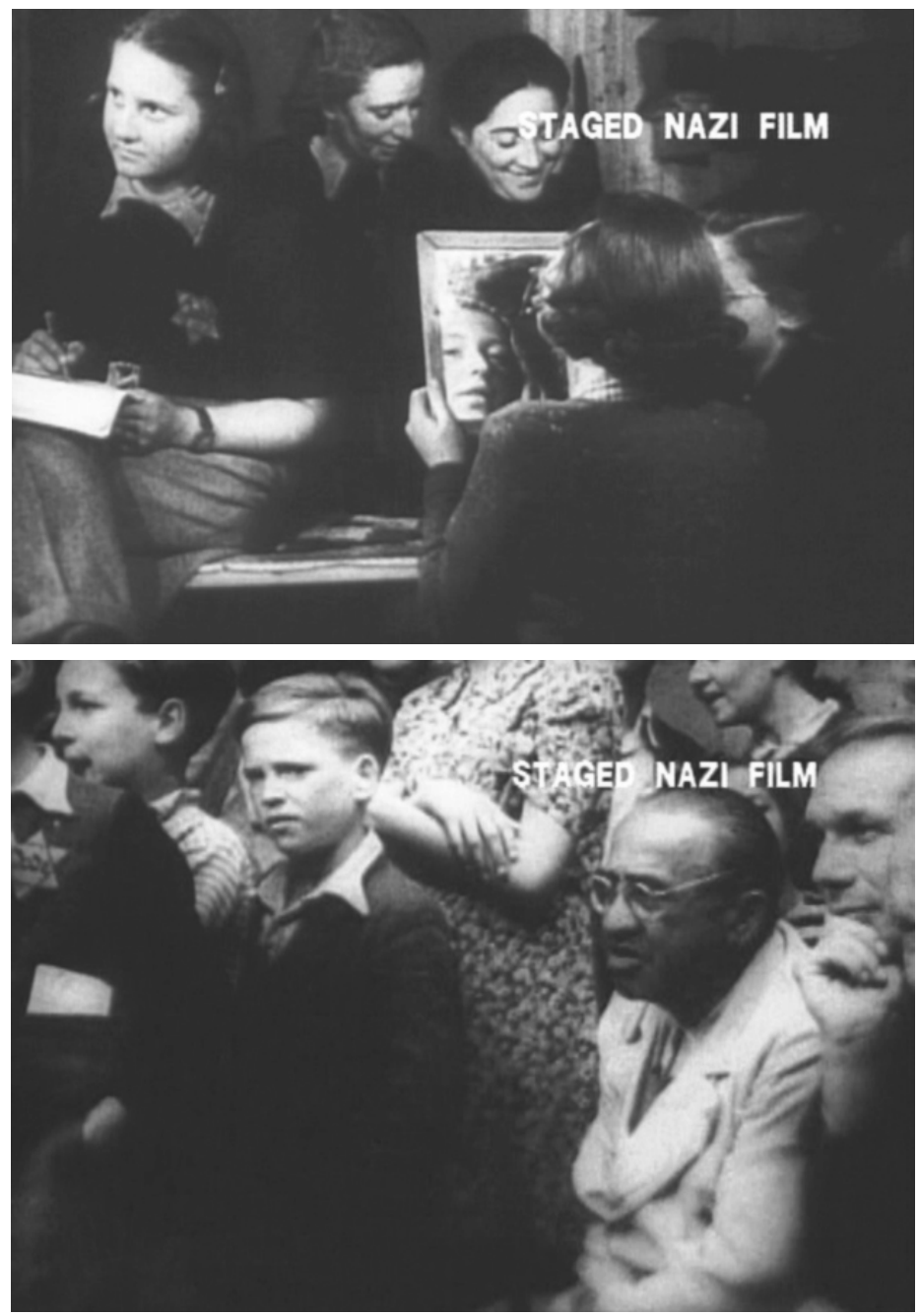

Est. Hist., Rio de Faneiro, vol. 26, no 51, p. 9-34, janeiro-junho de 2013. 
No entanto, alguns sinais vêm repentinamente nos lembrar, a partir da própria imagem, as condições de sua produção. Alguns figurantes não respeitam as ordens e lançam olhares furtivos para a câmera. No dormitório das mulheres, uma jovem filmada de costas observa a equipe de filmagem pelo reflexo de um espelho. No meio da multidão de figurantes, um menino desvia o olhar do jogo de futebol para lançá-lo sobre o cameraman. Através desses deslocamentos imperceptíveis, em que uma curiosidade sub-reptícia vence a obediência, olhares intensos vêm repentinamente de encontro aos nossos.

Outros indícios parecem revelar a rejeição da filmagem e o incômodo de estar associado a ela. Uma senhora protege o rosto com a mão para escapar da lente da câmera. Na saída do ateliê, no meio de figurantes sorridentes, uma mulher avança em direção ao cameraman com a expressão congelada, olhando para baixo; na altura da câmera, sua boca esboça um ricto imperceptível. Esses olhares e esses gestos "desafinados" criam uma distância, uma resistência; eles nos convidam a interrogar o lugar da câmera e o equipamento de gravação.

\section{Figura 9}

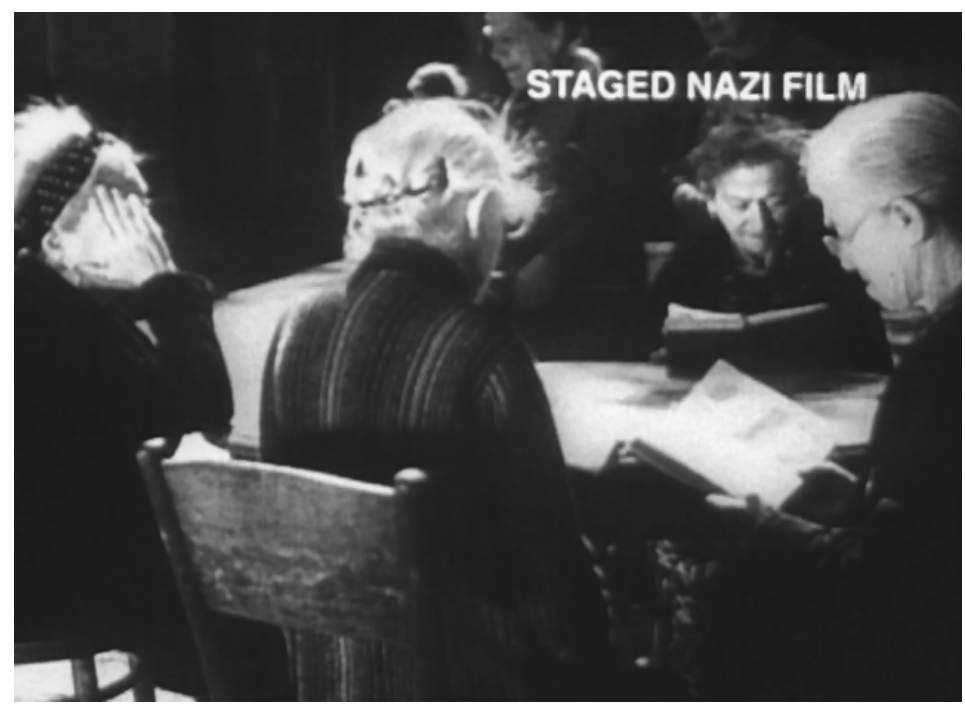

Os papéis de Gerron reunidos por Hans Günther Adler, que foi detento no campo-gueto antes de se tornar seu historiador, permitem vislumbrar a natureza única dessa filmagem, em que se imbricaram a pesada organização de um filme com recursos e o funcionamento administrativo de um campo nazista. ${ }^{13} \mathrm{O}$ cineasta se viu inserido em um duplo regime de restrições: algumas inerentes a 
uma filmagem de grande envergadura e seus inevitáveis imprevistos (materiais, técnicos, humanos e climáticos); outras próprias da burocracia nazista e da vontade de controle das SS. Essas duas lógicas nem sempre eram compatíveis. A realização de um filme exige decisões rápidas para que se possam fazer sem prejuízo as mudanças e ajustes necessários; a lei do campo e o funcionamento da hierarquia nazista impediam o cineasta de proceder com rapidez. A menor mudança no plano de filmagem exigia um pedido por escrito de Gerron, transmitido ao comandante Rahm por intermédio da administração judaica. Este último, por sua vez, comunicava à equipe de filmagem as ordens de Günther e não se abstinha de acrescentar as suas. Entretanto, para além do peso dos procedimentos burocráticos, a organização e a disciplina nazista foram postas a serviço de um filme que se baseou mais nos métodos tayloristas dos estúdios hollywoodianos do que nos das reportagens de atualidades. Durante várias semanas, o campo-gueto inteiro, seus ateliês, seus departamentos e seus internos foram requisitados e colocados à disposição da equipe. Edifícios foram desviados de sua função; locais inacessíveis aos detentos foram abertos durante a filmagem. Como a população internada em Terezín estava sujeita ao trabalho forçado, os serviços do campo puderam mobilizar sem descanso as massas de figurantes requeridas para as encenações. O encontro dessas duas máquinas, a cinematográfica e a dos campos de concentração, conduziu a imbricações perturbadoras. No dia 31 de agosto de 1944, a seção de lazer requisitou o interno judeu Wilhelm Brenner, que cumpria prisão punitiva. A Detektivabteilung, encarregada das funções de polícia, confirmou que o prisioneiro se apresentaria no dia seguinte no local da filmagem, mas acrescentou que tão logo as gravações tivessem terminado, ele deveria retornar à sua cela para cumprir sua pena. ${ }^{14}$ A Detektivabteilung foi novamente solicitada pela seção de lazer para investigar, no mesmo dia, o desaparecimento de um carnê de vales entregue a um figurante. ${ }^{15}$

Sinalizando a coação e a violência que lhes são feitas, as duas mulheres do filme - a que protesta e a que protege o rosto - nos fazem penetrar no centro das tensões dessa filmagem em regime disciplinar. De fato, se alguns internos sentiram prazer nela ou tentaram aproveitar a oportunidade, outros figurantes requisitados expressaram sua confusão diante daquela farsa sórdida. Alguns a expressaram por meio de um auto-escárnio. Este foi o caso do engenheiro Engelmann, químico alocado no laboratório médico de Terezín. Pedindo desculpas em carta à diretora do seu setor por ter faltado a um dia de trabalho, ele afirma ter sucumbido ao "chamado" de uma vocação de ator:

“passei pó no meu rosto, desenhei minhas sobrancelhas, derramei gotas de atropina em minhas pupilas, passei pomada nos cabelos e na barba: entro para o mundo do cinema. Começo como figu- 
rante, mas espero que seja apenas um trampolim. Sei que uma carreira me espera: sou jovem, bonito, irresistível..."

Ao comentar essa carta, Adler (1958) interpreta o humor de seu companheiro de internação no campo como uma última proteção contra a loucura. Os vestígios escritos dos internos, assim como os frágeis sinais que aparecem nas imagens, nos põem também diante da questão da "zona cinzenta" e interrogam os diversos graus de colaboração no seio da equipe de filmagem.

Se aceitamos considerar o filme de Terezín em toda a sua complexidade, percebemos certas características do evento cujas coordenadas a imagem recolhe. O filme acompanha duas características importantes da máquina de genocídio nazista: a conjunção entre a matança e a dissimulação, entre o crime e sua escamotagem estão inscritas no centro de Theresienstadt; a vontade de coagir os judeus a participar do processo de extermínio se prolonga na decisão de ordenar que os próprios internos façam o filme de propaganda.

No entanto, ao confiar a realização do documentário às suas vítimas, os nazistas contribuíram para modificar sua natureza. $\mathrm{O}$ exame da trilha musical nos leva mesmo a pensar que os internos inscreveram nela uma espécie de testamento. Composta pelas gravações dos concertos feitas por Gerron, ela foi completada em março de 1945 pela empresa Aktualita, a partir de escolhas feitas por outro judeu interno, Peter Deutsch. Esse compositor dinamarquês, que havia escrito antes da guerra diversas músicas de filmes, selecionou exclusivamente obras de compositores judeus; com isso, ele fez de Theresienstadt, ao longo do tempo, o local de refúgio de uma música banida. A trilha sonora do filme esconde por outro lado uma referência surpreendente. Nas cenas de hospital, escutamos diversos compassos do Kol Nidre. O texto dessa oração recitada para os mortos no Kippour constitui um verdadeiro enigma explorado pelo discurso antissemita para estigmatizar a duplicidade judia (Steiner, 2007). O texto em aramaico diz em essência: "que nossos votos não sejam vistos como votos, nem nossas promessas como promessas". Para esclarecer a presença dessa referência litúrgica na trilha sonora, Ophir Lévy lança a sedutora hipótese de uma "advertência codificada endereçada, no futuro, a um eventual público judeu: que essas imagens não sejam vistas como imagens verdadeiras, nem nossas palavras como dizendo a verdade". ${ }^{16}$ Assim a trilha sonora de Theresienstadt participaria, no sentido forte, dessa "arte de contrabando" cara a Louis Aragon, que a praticou nos seus poemas da Resistência.

Se o enigma do Kol Nidré não foi desfeito, ninguém pode duvidar que o tempo tenha frustrado o intento dos nazistas, trazendo-nos em sua "presença-ausência" perturbadora os rostos luminosos dos internos. Ao compor com delicadeza os retratos de seus companheiros de internação, Gerron foi de fato além 
da encomenda. Os nazistas haviam-no intimado a filmar uma lista de personalidades judias conhecidas no Grande Reich, cuja presença no vídeo deveria servir como uma efêmera prova de vida. Mas ao lado desses Prominenten, o cineasta se deteve nos rostos de mulheres e crianças escolhidas por sua beleza e não por sua notoriedade, para serem olhados e não para serem reconhecidos. Desses seres frágeis e ameaçados o filme faz figuras "eternas", ${ }^{17}$ como a do menino de olhos negros do Kindergarten cujo corpo grácil se aproxima e se distancia da câmera ao ritmo cadenciado de um cavalo de balanço.

A última particularidade de Theresienstadt vem do fato de que o filme recolhe também, pela música, as vozes dos perseguidos. As imagens das crianças da ópera Brundibár cantando sob um céu de papelão, tendo em vista uma morte anunciada, ilustram a visão de Françoise Proust de uma «música como assombração» e canto dos fantasmas:

"A música canta os restos: Singbarer Rest, diz Celan. A música canta o resíduo do sentido. Ela faz subir ao céu noturno esses pequenos fragmentos de sentido brilhantes e opacos que chamamos estrelas. Restos de sol incandescentes, de explosões extintas, as estrelas brilham atrás de nós com um esplendor opaco. Elas não clareiam nada, não iluminam nada, não são sinal de nada. Mas, tal qual alegorias espectrais, elas sinalizam que uma verdade está presente, explosiva e ardente, prestes a explodir e já calcinada.” (Proust, 1994: 101)

Esses planos sonoros contrastam com as imagens do cabaré de Westerbork, nas quais os atores internados, condenados a uma estranha mudez, se agitam na tela como mariposas capturadas pela armadilha da luz.

\section{Westerbork: o jogo duplo do cinema}

Filmado entre março e maio de 1944 pelo fotógrafo Rudolf Breslauer, o filme sobre Westerbork, mantido no estado de copião mudo não montado, ${ }^{18}$ é frequentemente comparado a Theresienstadt. À concordância cronológica das filmagens soma-se uma aparente similaridade das cenas referentes ao trabalho e ao lazer dos detentos, assim como a identidade dos diretores, ambos judeus alemães internados nos campos, a quem os nazistas ordenaram dirigir os filmes. Porém as apostas dos que encomendaram os filmes e as maneiras de filmar diferem profundamente. $\mathrm{O}$ documentário sobre Westerbork investe principalmente no ângulo cego de Theresienstadt, ao filmar a partida de um comboio com destino a 
Auschwitz; essas imagens, conhecidas por todos, circularam a partir do final dos anos 1940.

O filme foi rodado por iniciativa do comandante do campo, Albert Konrad Gemmeker. No início de 1944, ele ordenou a três judeus internados que concebessem um documentário sobre a vida e as atividades do campo, que entrava em um momento crucial de sua história. Embora a grande maioria dos judeus holandeses já tivesse sido deportada, pensou-se em converter Westerbork em Arbeitslager (campo de trabalho). Essa mudança de estatuto era ardentemente defendida por Gemmeker: ele temia o fechamento de Westerbork, o que poderia ter como consequência sua partida para os teatros de operações, locais ainda mais arriscados (Haan, 2004). Segundo os historiadores holandeses Koert Broersma e Gerard Rossing (1997), o filme teria sido portanto encomendado para justificar perante as autoridades nazistas de Berlim e da Haia a permanência do Lager Westerbork. $\mathrm{O}$ roteiro foi escrito pelo jornalista alemão Heinz Todtmann, judeu batizado que se tornou homem de confiança de Gemmeker e seu principal colaborador (Haan, 2004: 49).

A lógica dessa filmagem destinada a promover o "pequeno negócio" do comandante é atestada por sua sinopse e pelos materiais gráficos reunidos para o filme, entre os quais figura, sobretudo, um logotipo do campo. ${ }^{19}$

Figura 10

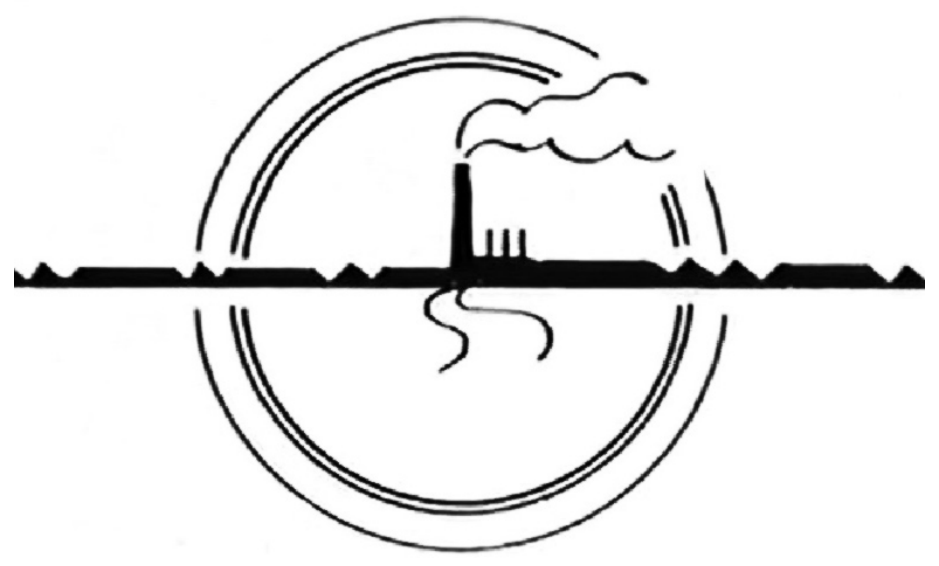

Para filmar o trabalho em Westerbork, Rudolf Breslauer e seu assistente Karl Jordan se conformaram aos códigos do filme de empresa, isolando em close-ups o gesto do operário, decompondo-o em câmera lenta, acompanhando o percurso da matéria sendo transformada em produto (desde o corte da madeira 
até a exposição dos brinquedos numa bancada, do desmonte dos motores dos aviões até sua reciclagem para a fabricação de pilhas).

Reencontramos a câmera lenta em uma das cenas do embarque do comboio que mostra a partida dos deportados para Bergen-Belsen e Auschwitz. A volta desse modo de filmar usado para promover o trabalho dos internos é perturbadora. Ela pode ser interpretada de várias maneiras.

$\mathrm{O}$ uso da câmera lenta poderia estar novamente relacionado à lógica do filme de empresa, encarando dessa vez a deportação e a destruição como uma atividade produtiva. Essa equivalência é expressa na animação gráfica no centro da qual foi colocado o logotipo de Westerbork; ela sinaliza com o auxílio de setas e indicações numéricas as "entradas" e as "saídas" (sobretudo para o leste) dos detentos do campo. ${ }^{20}$

\section{Figura 11}

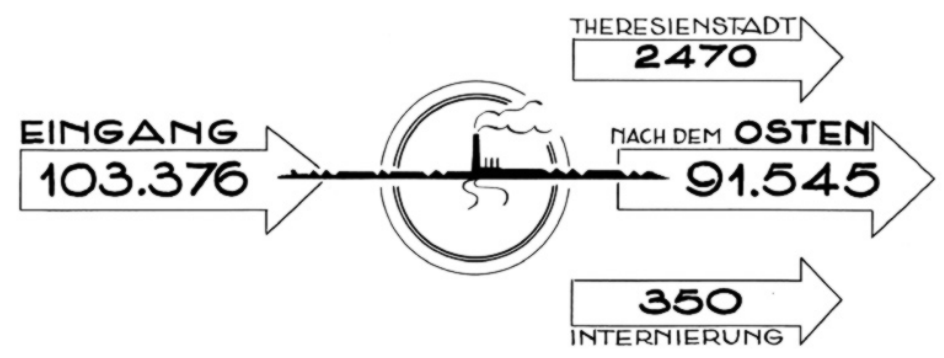

O gráfico e o roteiro evocam assim, sem rodeios, a dupla vocação de Westerbork: campo de trabalho $e$ local de trânsito. Eles entram, nesse sentido, na lógica extensiva de um filme de empresa que englobaria todos os aspectos do Lager. Por um comovente atalho, a sinopse e o desenho nos introduzem no coração da máquina de destruição nazista: a homologia entre os setores do trabalho e da deportação rebaixa os internos desumanizados ao nível de mercadorias, faz do morticínio uma indústria. ${ }^{21}$

Pode-se interpretar de forma bem diferente essa câmera lenta, levando em consideração as condições de filmagem das cenas de embarque. Se a sinopse de Todtmann preconizava o registro de imagens de "comboios partindo", Gem- 
meker não estava nem um pouco inclinado a fazê-lo, e expressou algumas reticências no momento da filmagem. Teria ele o pressentimento do poder de encarnação do cinema? As imagens de Breslauer cavam, na verdade, um fosso entre as palavras deitadas friamente sobre o papel e a operação de tradução realizada pela câmera em contato com e posta à prova do real. $\mathrm{O}$ cinema substitui a abstração das palavras de Todtmann ("Bilder von ausgehenden Transporten" / imagens dos comboios partindo) pela carga emocional dos rostos, pelo movimento dos corpos, pelo gesto seco do fechamento dos vagões, pela força expressiva de um olhar.

\section{Figura 12}

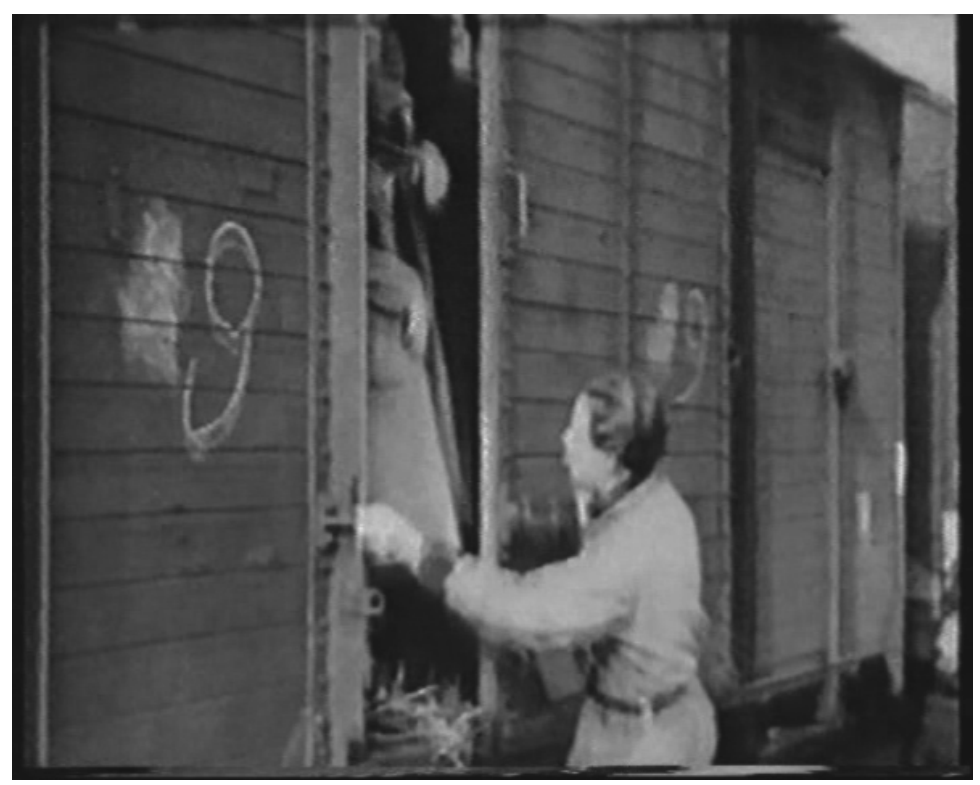

Nessa perspectiva, o movimento em câmera lenta de Breslauer assumiria outro significado; ele levaria simbolicamente a protelar a partida do comboio, a frear a marcha inexorável do trem, a manter os deportados na comunidade dos vivos. Não seria mais o caso de decompor um gesto, mas de conjurar o acontecimento.

Encontramos nos copiões de Westerbork as imagens de outro comboio, nitidamente mais bucólico. Várias cenas consagradas aos trabalhos externos, rodadas nos campos ou ao longo do canal, são filmadas por Breslauer de dentro de um pequeno trem do interior. $\mathrm{O}$ cameraman não é mais aqui uma testemunha impotente, imobilizada no cais. Ele sobe a bordo do trem, filma a paisagem cir- 
cundante e o balastro em plongée, se demora sobre a boca de fogo da locomotiva, descobre as construções da fazenda do campo onde algumas porcas e seus filhotes se divertem... Nós poderíamos opor termo a termo a filmagem dos dois trens: o trem da morte e o trem da liberdade que passeia os internos pelas charnecas, dando a essas cenas ares de um passeio no campo. Essa oposição nos convida a mais uma vez interrogar as condições da filmagem.

Figura 13

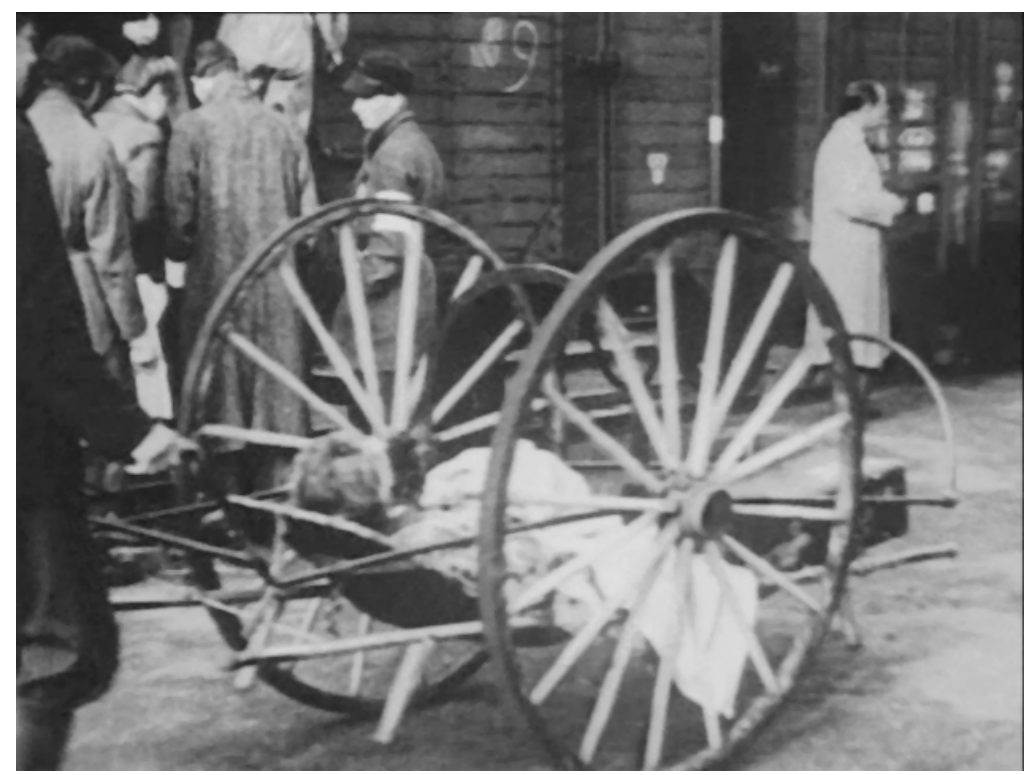

Para perceber seu alcance, é preciso ter em mente que esse filme de empresa foi feito por amadores pouco aguerridos que trabalharam com uma grande improvisação. Contrariamente à Gerron, Breslauer não parece ter exercido um controle excessivo sobre os internos filmados, aos quais foi dada certa liberdade de atuação. Assim, a inexperiência do cineasta amador teria tido como contrapartida a liberdade dada aos figurantes. Como num filme de família, as atitudes dos detentos de Westerbork diante da câmera variam: uns a ignoram, outros a observam ou fazem dela testemunha, dirigindo-lhe gestos, mímicas e risos. $\mathrm{O}$ conjunto da filmagem reserva uma parte importante à auto-encenação, como se os internos tivessem assumido o controle do filme e se apropriado dele.

A comparação com Theresienstadt é útil aqui também. A filmagem confiada a Gerron constituía uma temível armadilha para os detentos: ela negava a 
verdadeira natureza do campo-gueto e a ameaça que pesava sobre suas existências. O filme sobre Westerbork, ao justificar a reconversão do campo em Arbeitslager, visava ao contrário manter nos Países Baixos o comandante Gemmeker e os internos, todos ameaçados - de várias maneiras - de uma partida em direção ao Leste. Essa convergência de interesses poderia esclarecer a impressão difusa que brota das imagens de Breslauer: a de pessoas não totalmente constrangidas, participando do filme sem hostilidade.

A idéia de "sursis" 22 e de escapada pode, na verdade, ser estendida ao trabalho dos atores e da equipe de filmagem. Breslauer e Jordan parecem de fato ter-se beneficiado de uma relativa autonomia para aprontar sua encomenda. Os planos de exterior mostram uma equipe alegre, onde as pessoas filmadas e os cineastas aprendizes escapam literalmente do Lager. Na sequência do trenzinho, esse estado de leveza é simbolizado pela mecha de cabelo de uma interna que, esvoaçando ao vento, penetra intermitentemente no campo da câmera. Liberados da presença e da lei da SS, o diretor e os atores experimentavam, pela graça do filme, uma forma de liberdade recuperada. A verdade desses planos reside, nesse sentido, na reflexividade da filmagem: o "trabalho liberador" é o da câmera, o espaço comunitário é o que o filme organiza, obra coletiva na qual o cameraman e as pessoas que ele filma punham talvez suas últimas esperanças.

Se o filme de Westerbork permaneceu inacabado, suas imagens tiveram no período seguinte um destino contrastante. Os planos do embarque do comboio iniciaram no pós-guerra uma impressionante carreira cinematográfica, museográfica, editorial; em dezembro de 1948, eles revelaram toda a sua força acusatória, no julgamento de Gemmeker em Assen. As imagens projetadas no tribunal permitiram à Corte contemplar o comandante na sua glória passada, percorrendo a passos largos a rampa de Westerbork. O presidente considerou que a filmagem provava que ele era insensível ao destino trágico dos deportados. Se o acusado objetou que tinha querido registrar todos os aspectos do campo, os bons e os menos bons, ele afirmou também que não conhecia as imagens que acabavam de lhes ser mostradas. ${ }^{23}$ Como interpretar essa resposta, se é que ela exprime a verdade? $\mathrm{O}$ acusado, tendo precisado que os copiões do filme lhe haviam sido submetidos por imprimatur, operava uma divisão entre os planos de trabalho ou de lazer e os do embarque para Auschwitz. Se ele não ignorou nada das filmagens, como atesta o plano em que ele observa a câmera com ar seguro, essas últimas imagens talvez não lhe tenham sido mostradas por Breslauer, que pressentia sua força de testemunho. A declaração Gemmeker pode também ser interpretada em um sentido menos literal: ela testemunha o que ele não quis nem conhecer nem compreender ao assistir às partidas semanais dos comboios. O tempo das imagens frustra assim o desígnio dos carrascos: ele se volta contra eles revelando aquilo que eles não eram capazes de perceber no cumprimento implacável e cego 
de suas tarefas criminosas. Foi portanto diante do tribunal de Assen que Gemmeker finalmente olhou para os deportados, percebeu os efeitos de seus atos. Foi em Assen que ele descobriu a força incandescente do plano da menina com o lenço que se transformaria durante longas décadas numa imagem ícone da Shoah (figura 14).

Figura 14

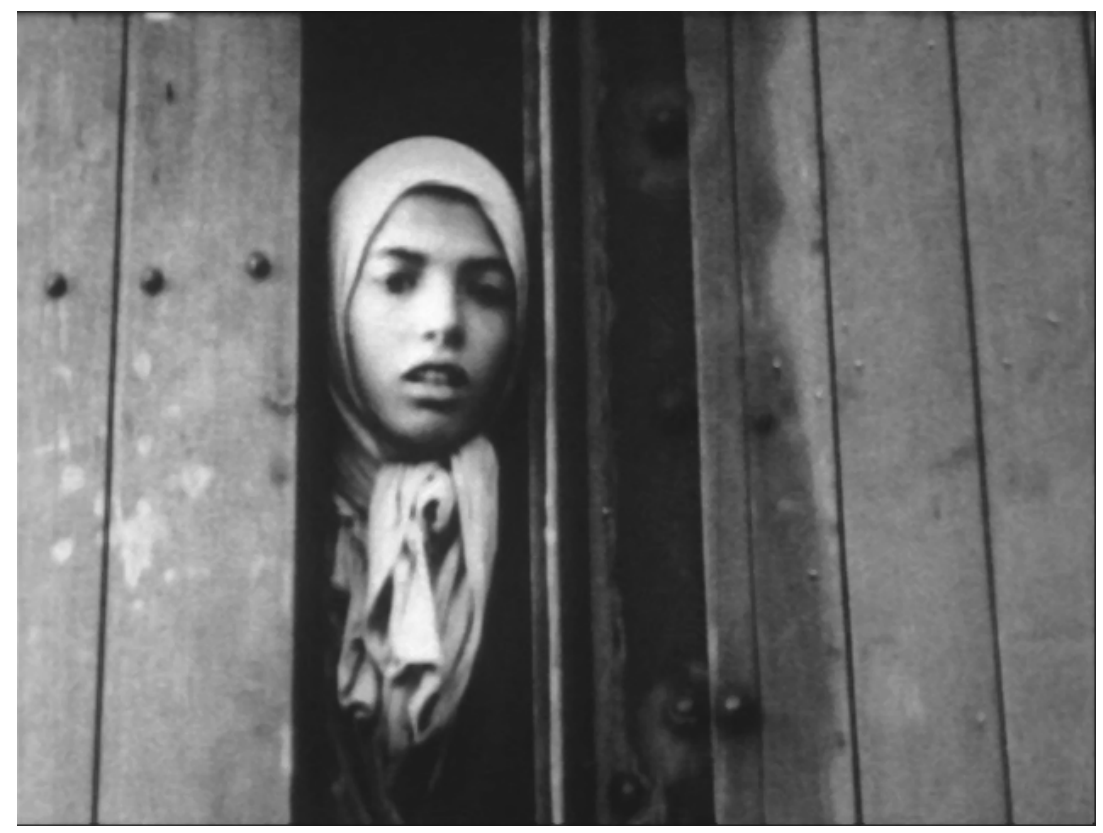

A eleição deste plano como símbolo do genocídio judeu foi reforçada durante longo tempo pelo anonimato da criança e pelo postulado de sua morte que transfigurava sua imagem em vestígio de uma ausência e de um desaparecimento. Esse estatuto foi revisto em 1994 por uma pesquisa feita pelo jornalista holandês Aad Wagenaar com a colaboração de Koert Broersma. Os anos 1990 foram marcados pela vontade de tornar a dar um nome às vítimas do nazismo; nesse contexto, Wagenaar sentiu a necessidade imperiosa de identificar a criança do rosto familiar. ${ }^{24}$ Ao final de dois anos de investigação, ele descobriu que a menina se chamava Anna Maria Settela Steinbach: ela havia sido assassinada em Auschwitz aos nove anos de idade; ela era Sinti e não Judia.

Broersma ajudou Wagenaar a datar o comboio. Ele examinou a cópia em câmera lenta, se deteve sobre a imagem da figura inválida deitada sobre uma maca (figura 13), ampliou a inscrição em tinta branca na sua mala. Conseguiu 
então desvendar o nome de Frouwke Kroon. Internada em Westerbork, ela fora deportada em 19 de maio de 1944 e foi morta na câmera de gás assim que chegou a Birkenau. Essa identificação permitiu a Wagenaar reencontrar vários sobreviventes desse transporte que conduziu para Auschwitz 208 Judeus e 245 Ciganos.

No seu filme Settela. Visage du passé (1994), Cherry Duyns reconstitui as principais etapas dessa pesquisa. Ele mostra Koert Broersma procurando indícios, examinando a cópia em uma mesa de edição, fazendo uma série de gestos que lembram os do fotógrafo de Blow up: nós o vemos fazer voltar a película sobre os cabeçotes de leitura, desacelerar a imagem e pará-la para fazer uma ampliação e finalmente ler o nome da enferma registrado sobre a mala, impresso no celulóide como "em um livro de Deus". ${ }^{25}$ Por esses movimentos de câmera lenta e parada, Broersma coloca inconscientemente seus passos na trilha dos de Breslauer. Ele age também como um poderoso revelador, desvendando os elementos que jazem sob a película, iluminando a textura espectral das imagens.

O contraste é evidente entre a atenção apaixonada dirigida às imagens do comboio e o desinteresse que foi reservado às cenas de trabalho e lazer. Essas cenas negligenciadas evocavam o desconforto e o constrangimento. Assim como naquelas Theresienstadt, as imagens do cabaré de Westerbork ou de moças sorridentes entregues a exercícios de ginástica à sombra de uma torre de controle levantavam questões que incomodavam. No entanto, essas cenas filmadas nos ajudam: para além do desígnio propagandista dos nazistas, elas transmitem através do tempo, como astros mortos, os últimos vestígios dos personagens filmados por ordem de seus carrascos, as mensagens complexas e ambivalentes dos que filmaram contra a vontade.

Assim, nossa relação com essas imagens aparece estruturalmente regida por uma temporalidade dupla. Ela é feita de um incessante vai-e-vem entre seu valor indicial e sua força espectral. A primeira temporalidade nos obriga a voltar no tempo até o ponto de origem do registro da imagem, a documentar esse momento singular, a historicizá-lo. Ela exige que não falseemos o sentido das imagens projetando nelas nosso conhecimento retrospectivo, sobrecarregando-as com nossos afetos, nossos humores, com as expectativas simbólicas e sociais de nosso presente. A segunda temporalidade leva em conta o tempo irremediavelmente decorrido, sua espessura, sua estratificação, que tornam essas imagens para nós radicalmente outras. Não é nem possível nem provavelmente desejável retornarmos inocentemente ao ponto da gravação, nos "desinformarmos" sobre o destino trágico das pobres sombras que se movem na tela. Por meio dessa aliança de distância e proximidade, o tempo que nos separa das imagens de arquivo convida a retomar o diálogo com esses homens e essas mulheres filmados no limiar de suas mortes, passados para o estado de fantasmas, que retornam para assombrar nosso presente. 
1. Para retomar a expressão de Carlo Ginzburg a propósito dos processos da Inquisição.

2. Suzanne de Troye, Roger e Victoria Mercanton.

3. Presidente do Conselho Nacional da Resistência.

4. O retrato que dele faz René Dunan evoca seus feitos e sua notoriedade repentina. A descrição não está livre de preconceitos raciais e de um imaginário colonial bastante datado: o jornalista pinta Dukson com os traços de um jovem ingênuo de pele reluzente, partindo ao assalto de tanques com os pés e o torso nus. As imagens do filme La Libération de Paris o mostram calçado e vestido...

5. Foto publicada na obra de Pierre Bourget, Paris 1940-1944 (1979), e comentada junto com outras por Eric Lafon no site da Fondation de la Résistance "Histoire d'une photographie".

6. Ficha de Georges Primoult, Dukson Georges (1922-1944), in La Résistance en Île de France, DVD-Rom (Paris: Ed. AERI, 2004).

7. Devemos a história detalhada do filme ao trabalho amplo e documentado do pesquisador holandês Karel Margry. Ver Magry (1992: 145-162).

8. Inicialmente ator de teatro em Berlim, Gerron ficou conhecido por seus espetáculos de cabaré e ganhou fama no cinema como parceiro de Marlene Dietrich em $O$ Anjo Azul. Começou a dirigir em 1931 para a UFA. Ver Felsmann e Prümm (1992).

9. Por ocasião, sobretudo, da nova visita da Cruz Vermelha, no dia 6 de abril de 1945. Ver Margry (1992: 147-148).
10. Entre 24 e 25 minutos, dependendo das versões. Faço aqui referência àquela conservada pelo National Center for Jewish Film, completada, no que diz respeito a duas cenas que faltavam, por uma visualização nos Bundesarchiv Filmarchiv.

11. Segundo a expressão utilizada por Eppstein no seu discurso introdutório, por ocasião da visita de Maurice Rossel.

12. Cúmulo do cinismo, como o comandante Karl Rahm havia deportado muitos doentes antes da chegada da delegação da Cruz Vermelha, estes foram - para a visita - substituídos nos leitos por indivíduos “saudáveis". Ver Berkeley (1993: 175).

13. Os documentos de Gerron reunidos pelo historiador H.G. Adler foram depositados em Amsterdã no Nederlands Instituut voor Oorlogsdocumentatie (NIOD, fonds Adler, $12 \mathrm{~F}$ ); esses documentos estão atualmente emprestados ao pesquisador Karel Margry em Utrecht, onde os consultei.

14. Carta do chefe da Detektivabteilung do dia 31 de agosto de 1944 (NIOD, fonds Adler, 12F).

15. Carta da Freizeitgestaltung à Detektivabteilung, 31/8/1944 (NIOD, fonds Adler, 12F).

16. Ophir Levy, correspondência com a autora, 8 de outubro de 2008.

17. Chris Marker, Si j'avais quatre dromadaires (1966).

18. A duração total dos diferentes copiões conservados é de 95 minutos. Outros planos poderiam existir nos negativos originais, que não foram encontrados. 
19. Esse documento constituiu uma das revelações do filme de Harun Farocki, Respite, En Sursis, Aufschub (2007).

20. Arquivos do Instituto Holandês de Documentação de Guerra de Amsterdã (NIOD Collection 250 i Camp Westerbork/ Film en toneel $\mathrm{n}^{\circ} 854$ ).

21. Com relação a esta questão, ver Elsaesser (2009: 66).

22. Para retomar o título do filme de Harun Farocki. Sursis significa suspensão condicional da pena.

23. Was Sie mir da zeigen kenne ich noch nicht (o que vocês acabam de me mostrar, eu não conhecia), extraído das minutas do

Referências bibliográficas

ADLER, H.G. Die verheimlichte Wahrheit. Theresienstädter Dokumente. Tübingen: Mohr, 1958.

ARASSE, Daniel. Le détail. Pour une histoire rapprochée de la peinture. Paris: Flammarion, 1992 ; rééd. Collection Champs, 1996.

BERKLEY, G. E. Hitler's gift. The story of Theresienstadt. Boston: Branden Books, 1993.

BOURGET, Pierre. Paris 1940-1944. Paris: Plon, 1979.

BROERSMA, Koert et ROSSING, Gerard. Kamp Westerbork gefilmd, Westerbork Cahiers 5. Assen: Éd. Herinneringscentrum Kamp Westerbork-Van Gorcum \& Comp, 1997.

CERTEAU, Michel de. L'absent de l'histoire. Tours: Mame, 1973.

COMOLLI Jean-Louis. Cinéma contre spectacle. Lagrasse: Verdier, 2009. processo de Gemmeker (Kibboutz des combattants du ghetto, Beit Lohamei Haghetaot, cote 3437/NIOD Coll. DOC I 250i Gemmeker n`520/ d 2).

24. Sua obra, publicada em holandês em 1995, foi traduzida para o inglês dez anos depois por Janna Eliot. Ver Wagenaar, 2005.

25. Para retomar a expressão de Harun Farocki em Bilder der Welt und Inschrift des Krieges (1988).

DUNAN, René. «Ceux» de Paris. Août 1944. Genève: Editions du Milieu du Monde, 1945.

ELSAESSER, Thomas. Holocaust memory as an epistemology of forgetting? Rewind and postponement in Respite, in Harun Farocki. Against what? Against whom? dir. Antje Ehmann et Kodwo Eshun. Londres: Koenig Books, Raven Row, 2009.

FELSMANN, Barbara et PRÜMM Karl. Kurt Gerron - Gefeiert und gejagt. 1897-1944. Das Schicksal eines deutschen Unterhaltungskünstlers. Berlin: Éd. Hentrich, 1992.

HAAN, Ido de. Vivre sur le seuil. Le camp de Westerbork dans l'histoire et la mémoire des Pays-Bas, Revue d'Histoire de la Shoah, CDJC, n' 181 , juillet-décembre 2004, p. 37-60.

LARDELLIER, Pascal. Image incarnée. Une généalogie du portrait politique, in 
revue $M E I$, Médiation et information, $\mathrm{n}^{\circ} 7$, 1997.

LESSING, Gotthold Ephraim. Laocoon ou des frontières de la peinture et de la poésie, préface d'Hubert Damish. Paris: Éd. Hermann, 1990; réed. 2002.

LINDEPERG, Sylvie. La voie des images. Quatre histoires de tournage au printemps-été 1944. Lagrasse: Verdier, 2013.

MARGRY, Karel. Theresienstadt (19441945): the nazi propaganda film depicting the concentration camp as paradise, in $\mathrm{His}$ torical Fournal of Film, Radio and Television, vol. 12, n², 1992, p. 145-162.
PROUST, Françoise. L'histoire à contretemps. Le temps historique chez Walter Benjamin. Paris: Éd. du Cerf, 1994.

SEBALD, Winfried Georg. Austerlitz. Arles: Actes Sud, 2002 ; rééd. Gallimard, collection Folio 2008.

STEINER, Michel. Le Kol Nidré. Etude psychanalytique d'une prière juive. Paris: Éditions Hors commerce, 2007.

WAGENAAR, Aad. Settela, trad. Janna Eliot. Nottingham: Five Leaves Publications, 2005.

\section{Resumo}

Este texto reconstrói três histórias de filmagens realizadas na primavera-verão de 1944, na Paris insurgente e nos campos de trânsito de Terezín, na Tchecoslováquia, e de Westerbork, na Holanda. A volta ao ponto de origem das imagens permite entrever o universo mental daqueles que as filmaram e interrogar suas escolhas. Ela revela seu imaginário a respeito do evento, sua vontade de conformá-lo à ideia que fazem dele, às vezes suas dificuldades de entender o que se passa. Esses planos recolhem também o impensado de uma época, a parte incompreensível da história para os contemporâneos. Eles conservam o que escapou ao olhar do cameraman na gravação mecânica de uma fatia do real. Os planos analisados abrem assim o caminho, até mesmo em sua fragilidade e em suas lacunas, para uma história do sensível próxima daqueles que fizeram o evento ou foram suas vítimas. Eles incitam questões tais como o lugar da arte no coração da barbárie, as ambivalências do "colaboracionismo artístico", a capacidade do cinema de se tornar um instrumento de liberação ou de resistência.

Palavras-chave: cinema; imagens de arquivo; história; Liberação de Paris; Resistência Francesa; campo de trânsito; nazismo.

\section{Abstract}

This text is about three film shots in the spring and summer of 1944, in an insurgent Paris and in the transit camps of Terezín in Czechoslovakia and Westerbork in The Netherlands. Going back to the origin of the images 
allows us to understand the minds of those who filmed them and to inquire their choices. It reveals their mental image of an event, their desire to make the event conform to their idea of it, and the difficulties they occasionally have in grasping what is going on. These shots also contain the part of history that is unintelligible to contemporaries. They preserve what the operator failed to see while mechanically recording a portion of reality. Thus the analyzed shots, fragile and deficient as they are, pave the way for a history as close as possible to those who made the event or were its victims. They open up questions such as the part art plays at the heart of barbarism, the ambivalence of so-called artistic collaboration, and the ability of cinema to become an instrument of liberation or resistance.

Keywords: cinema; archival images; history; Liberation of Paris; French Resistance; transit camp; nazism.

\section{Résumé}

Ce texte retrace trois histoires de tournages effectués au printemps-été 1944 dans Paris insurgé, et dans les camps de transit de Terezin en Tchécoslovaquie et de Westerbork aux Pays-Bas. La remontée vers le point d'origine de la prise de vue permet d'entrevoir l'univers mental de ceux qui filmèrent, d'interroger leurs gestes et leurs choix. Elle dévoile leur imaginaire de l'événement, leur volonté de le conformer à l'idée qu'ils s'en font, leurs difficultés parfois à en saisir le déroulé. Ces plans recueillent aussi l'impensé d'une époque, la part inintelligible de l'histoire pour les contemporains. Ils conservent ce qui échappa au regard de l'opérateur dans l'enregistrement mécanique d'une portion de réel. Les plans analysés ouvrent ainsi la voie, jusque dans leur fragilité et leurs manques, à une histoire du sensible inscrite au plus près des corps de ceux qui firent l'événement ou qui en furent victimes. Ils engagent des questions telles que la place de l'art au cœur de la barbarie, les ambivalences de la "collaboration artistique», la capacité du cinéma à devenir un instrument de libération ou de résistance.

Mots-clés: cinéma; images d'archives; histoire; Libération; résistance; camp de transit; nazisme. 